\title{
Assessment of the ecological well-being of the rivers of the Middle Urals in areas with increased technogenic load
}

\author{
M. O. Gutova ${ }^{1 区}$, Kh. E. Flefel ${ }^{1}$, M. S. Andryushechkina ${ }^{1}$ \\ ${ }^{1}$ Ural State Agrarian University, Ekaterinburg, Russia \\ E-mail:maaniassha@mail.ru
}

\begin{abstract}
The purpose of our work was to assess the chemical composition and physicochemical properties of surface water bodies exposed to industrial enterprises and located in close proximity to agricultural land. The environmental condition of industrial regions is determined by the specifics of their development. Recently, vast territories of cities and agricultural lands have been subjected to a high degree of technogenic pollution, which is caused by excessive concentration of production and its continuous and long-term negative impact on natural complexes, which causes a sharp reduction in natural resource potential and its degradation [1, p. 200]. Methods. The article examined the ecological status of flowing water bodies in some areas of the Sverdlovsk region. Assessment of the ecological state of the rivers was assessed by physicochemical and chemical indicators, which included mineralization, hydrogen, and the concentration of salts of heavy metals. Results. During the study, we took water samples from 5 rivers flowing in areas with different technogenic loads. In the hot study, violations were identified by physico-chemical and chemical indicators. At the same time, excesses in mineralization were noted in the rivers of the Artinskiy district, indicators here ranged from 335, which refers to the average mineralization group up to $509 \mathrm{mg} / \mathrm{dm} 3$, which refers the river to the group of mineralization increased, almost all the rivers under study have a neutral reaction in terms of hydrogen value. The excess of MPC was noted in the rivers mainly cobalt, manganese, copper, nickel, lead and zinc, while the excess for various metals ranged from 1 to 32 MPC. Scientific novelty. As a result of the study, the most polluted of the rivers studied by us was determined, which is located in the zone of increased technogenic load and it is noted that the maximum concentration of pollutants falls on the Kamenskiy district.
\end{abstract}

Keywords: heavy metals, physico-chemical indicators, natural water sources, water pollution, industrial pollution.

For citation: Gutova M. O., Flefel Kh. E., Andryushechkina M. S. Assessment of the ecological well-being of the rivers of the Middle Urals in areas with increased technogenic load // Agrarian Bulletin of the Urals. 2020. No. 07 (198). Pp. 41-46. DOI:

Paper submitted: 11.05.2020.

\section{Introduction}

Among many problems of modern society, environmental protection takes one of the first places. Today, more than half of the world's population lives in cities, and the proportion of the urban population is growing steadily. Cities have become centers of concentration of the population, industry and, as a result, intense environmental pollution, which, in accordance with the area of toxicant anomalies, is a technogenic geochemical province. In the process of human activity there is a constant withdrawal of resources, their transfer, processing and return to nature. Cities, urban areas are the final links in the supply chain. A special role in environmental monitoring and assessment of the ecological condition of the area is given to the study of heavy metals, which occupy one of the leading places in the list of pollutants [3].

The aim of our work was to assess the chemical composition and physicochemical properties of surface watercourse exposed to industrial enterprises and located in close proximity to agricultural land.

There are various definitions of the term "heavy metals". The list, according to each of them, will contain different elements. A frequently used criterion is a density approximately equal to or greater than the density of iron $(8 \mathrm{~g} / \mathrm{cm} 3)$ or more, and then elements such as lead, copper, cadmium, cobalt, zinc are on the list. Heavy metals are highly toxic, many of them also with the ability to accumulate in living organisms. Many metals form stable organic compounds; the good solubility of these complexes promotes the migration of heavy metals in natural waters. Heavy metals include more than 40 chemical elements, but taking into account toxicity, resistance, ability to accumulate in the environment and the extent of the spread of toxic control compounds, it requires about four times less number of elements.

The ecology of the Urals is actively spoiled by dozens of enterprises of the oil refining and oil producing industries, the territory is poisoned by industrial waste located in landfills and landfills, for which thousands of hectares of land are allocated [2].

On the territory of the Middle Urals there are organizations operating radiation-active facilities, monazite concentrate warehouses, significant territories exposed to radioactive contamination as a result of the accident at the "Mayak" production association (East Ural Radioactive Trace) [4, p. 4].

Toxic substances fall into the water mainly with industrial wastewater, with smoke and dust from industrial enterprises, products of automobile fuel combustion, as a result of the use 
of pesticides and herbicides in agriculture. Despite their low concentration in water $(\mu \mathrm{g} / \mathrm{l})$, they can cause significant harm to human health.

Water bodies located near mining facilities, ferrous and non-ferrous metallurgy, are heavily polluted by heavy metals. In addition, the surface waters of the Urals are actively polluted by oil products.

As a result, the average level of pollution of the Ural river waters far exceeds the maximum permissible level. Moreover, only a fifth of the water supply system of the Ural region carries out a full cycle of drinking water purification [2].

Due to the long-term effects of technogenic factors, most surface water sources near Yekaterinburg, Kamensk-Uralsky have a high degree of pollution, which is chronic in terms of the content of metals, oil products, and bacterial contamination. Similar problems are typical for almost all rivers flowing through industrially developed areas of the region and large industrial cities, which, accordingly, determines the limitation on the possibility of using river water resources $[1, \mathrm{p} .8]$.

The content of heavy metals salts in water sources should be checked from time to time, since their accumulation will cause many problems for a living creature [16, p. 117]. As a result of the toxicants action, there occur significant shifts in the functions of individual body systems. The degree of anthropogenic impact in the territory of the location of dairy farms affects the realization of the biological potential of animals, the state of animal health, epizootological well-being and the quality of the products [18, p. 26].

Heavy metals are part of enzymes, vitamins, hormones. These compounds actively influence the change in the intensity of metabolic processes in living organisms. It is because of this the content of heavy metals in water is normalized, because an increase in their concentrations can cause disruption of biological processes in living organisms and lead to their diseases (often chronic), as well as to their death.

Reaching a certain concentration in the body, they begin a fatal effect: they cause poisoning, mutations, clog the renal channels, liver channels, reducing the filtering ability of these organs. Accordingly, this leads to the accumulation of toxins and vital products of the cells of our body, the body is selfpoisoning, since the liver is responsible for the processing of toxic substances, and the kidneys are responsible for their removal.

As our studies show, lead, cobalt and zinc accounted for the largest excess of permissible concentrations of heavy metals in the rivers of the Middle Urals.

The main sources of lead in the environment are industrial emissions, the use of leaded gasoline, the use of lead-containing solders in the canning industry, lead-containing paints, and lead

materials in plumbing systems. Exceeding lead concentrations is especially dangerous for mammalian animals because lead is transported by red blood cells in peripheral blood and accumulates mainly in the liver, kidneys and bone tissue. The toxic effect of lead on mammals is determined by its content in organs and tissues. Lead is excreted from the body with feces and urine, as well as through wool, milk, sweat glands and the fetus. The half-life of metal from soft tissues and peripheral blood is 24-40 days. The toxic effect of lead in the organs and tissues of mammals is characterized by a decrease in the number of viable cells [17].

The main source of zinc in natural waters is the mineral sphalerite $(\mathrm{ZnS})$. Almost all zinc compounds are highly soluble in water. As a result, unlike some other metals, zinc is distributed in waters. In river waters, its concentration ranges from several micrograms to tens, and sometimes hundreds of micrograms per liter. High concentrations of zinc can be mutagenic and oncogenic.

The main sources of cobalt in the environment are non-ferrous smelters, transport, fertilizers and pesticides, galvanization, and the burning of hydrocarbon fuels in various industries.

Despite the fact that excessive intake of cobalt in the body is quite rare, this process is accompanied by various health disorders, for example, an excess of cobalt can lead to a violation of iodine metabolism in the thyroid gland [19, p. 45].

\section{Methods}

To conduct the study, we took water samples from the rivers of the Sverdlovsk region.

The list of studied reservoirs is presented in table 1 .

When choosing the investigated surface water bodies, the obligatory item was the presence of agricultural enterprises in zones with different technogenic loads that are located in close proximity to the water body and use water from it for the needs of the economy.

The selected rivers are located in three conditionally allocated zones: the zone of high technogenic load - the Pozarishka river, flowing in the Kamenskiy district; the medium technogenic load zone is the Brusyanka river of the Beloyarskiy district, the Baltym river, which belongs to the Verkhnyaya Pyshma urban district; the zone of low technogenic load is the Iset' River of the Sysert' District and the Manchazh River of the Artinskiy District.

Water samples were taken according to all-Union State Standard 31861-2012 "Water. General requirements for sampling" manually with a special device from a depth of $50 \mathrm{~cm}$ in a plastic container with tightly screwed caps. After selection, the water was acidified with nitric acid at the rate of $1 \mathrm{ml}$ of acid per 1 liter of water and stored until analysis.

Table 1

Researched reservoirs

\begin{tabular}{|c|l|l|}
\hline No. & \multicolumn{1}{|c|}{ Substation river } & \multicolumn{1}{c|}{ Address } \\
\hline 1 & Pozarishka & Sverdlovsk region, Kamenskiy district, Pozarishka \\
\hline 2 & Brusyanka & Sverdlovsk region, Beloyarskiy district, Studencheskiy \\
\hline 3 & Iset' & Sverdlovsk region, Sysert' district, Bol'shoy Istok \\
\hline 4 & Baltym & Sverdlovsk region, Verkhnyaya Pyshma, Sadovyy \\
\hline 5 & Manchazh & Sverdlovsk region, Artinskiy district, Manchazh \\
\hline
\end{tabular}


Table 2

The chemical composition of water in the Sverdlovsk region, $\mathrm{mg} / \mathrm{dm}^{3}$ Result \pm absolute error with probability $P=0.95$

\begin{tabular}{|c|c|c|c|c|c|c|}
\hline Index & r. Pozarishka & r. Brusyanka & r. Iset' & r. Baltym & r. Manchazh & MPC \\
\hline Cadmium (Cd) & $0.0063 \pm 0.0019$ & $0.0047 \pm 0,0014$ & $0.0031 \pm 0.0009$ & $0.0047 \pm 0.0014$ & $0.0015 \pm 0.0005$ & 0.005 \\
\hline Cobalt (Co) & $0.317 \pm 0.079$ & $0.121 \pm 0.030$ & $0.138 \pm 0.035$ & $0.105 \pm 0.026$ & $0.043 \pm 0.011$ & 0.010 \\
\hline Manganese (Mn) & $0.019 \pm 0.006$ & $0.016 \pm 0.005$ & $0.013 \pm 0.004$ & $0.013 \pm 0.004$ & $0.013 \pm 0.004$ & 0.010 \\
\hline Copper (Cu) & $0.012 \pm 0.003$ & $0.010 \pm 0.003$ & $0.006 \pm 0.002$ & $0.008 \pm 0.002$ & $0.003 \pm 0.001$ & 0.001 \\
\hline Nickel (Ni) & $0.103 \pm 0.026$ & $0.086 \pm 0.022$ & $0.035 \pm 0.011$ & $0.086 \pm 0.022$ & $0.069 \pm 0.017$ & 0.010 \\
\hline Lead $(P b)$ & $0.106 \pm 0.027$ & $0.083 \pm 0.021$ & $0.062 \pm 0.016$ & $0.083 \pm 0.021$ & $0.106 \pm 0.027$ & 0.006 \\
\hline Zinc $(Z n)$ & $0.057 \pm 0.016$ & $0.187 \pm 0.037$ & $0.063 \pm 0.018$ & $0.084 \pm 0.024$ & $0.107 \pm 0.021$ & 0.010 \\
\hline
\end{tabular}

The following series of hydrochemical indicators were determined in the selected water samples: $\mathrm{pH}$, mineralization, and content of heavy metals. Analysis for the content of $\mathrm{Mn}, \mathrm{Co}, \mathrm{Ni}, \mathrm{Cu}, \mathrm{Zn}, \mathrm{Cd}, \mathrm{Pb}$ in water was carried out after preliminary filtration according to PNP F 14.1: 2: 4.13998 (2010) on a flame atomic absorption spectrophotometer. Mixtures of GSO of individual ions were used as calibration solutions. To construct the calibration curves, we used the nonlinear dependence of the spectrophotometer readings on a scale of percent absorption $\mathrm{Y}$ on the concentration of an element $\mathrm{C}$ of the form: $\mathrm{Y}=(100+\mathrm{aC}) /(1+\mathrm{bC})$.

Characterization of water quality was carried out according to all-Union State Standard 17.1.2.04-77 "Nature protection. Hydrosphere. Status indicators and taxation rules for fishery water bodies", according to which stiffness, $\mathrm{pH}$ and concentration of harmful substances were taken into account.

Results

The measurement of $\mathrm{pH}$ is important and often determined by tests to analyze water quality. $\mathrm{PH}$ of water is important because it affects the solubility and accessibility of nutrients, as well as how they can be used by aquatic organisms $[8, \mathrm{p}$. 3420].

According to studies, the $\mathrm{pH}$ was neutral, close to slightly alkaline, the indicators of different rivers did not differ much from each other and ranged from a minimum of 6.8 to a maximum of 7.28 in the Iset and Brusyanka rivers, respectively.

Typically, the $\mathrm{pH}$ level is within the range at which it does not directly affect the consumer quality of the water. So, in river waters, the $\mathrm{pH}$ is usually in the range of 6.5-8.5. Therefore, WHO does not offer any recommended medical values for $\mathrm{pH}$. However, it is known that at low $\mathrm{pH}$, water has high corrosivity, and at high levels $(\mathrm{pH}>11)$, water acquires a characteristic soapiness, an unpleasant odor, and can cause irritation to the eyes and skin. That is why for drinking and household water, the $\mathrm{pH}$ level in the range from 6 to 9 is considered optimal. In addition, the $\mathrm{pH}$ range, which is not lethal for fish, is from 5 to $9[9$, p. 3$]$.
According to the classification of O. A. Alekin, according to the mineralization degree, the water in the Pozarishka River belongs to the group of increased mineralization $\left(509 \mathrm{mg} / \mathrm{dm}^{3}\right)$, but is close to the average group $\left(200-500 \mathrm{mg} / \mathrm{dm}^{3}\right)$, the maximum level of mineralization of all investigated.

Water in the Brusyanka and Manchazh rivers belongs to the average degree of mineralization and has indicators of 227 $\mathrm{mg} / \mathrm{dm} 3$ and $335 \mathrm{mg} / \mathrm{dm} 3$, respectively. And in the Iset' and Baltym rivers, water has a low degree of mineralization with indicators of $138 \mathrm{mg} / \mathrm{dm} 3$ and $148 \mathrm{mg} / \mathrm{dm} 3$, respectively.

High rates of dissolved solids in water may be a criterion for the natural parameters of water, but at the same time they may indicate the ingress of organic substances and solid waste into the river [6, p. 44].

Total mineralization is the total quantitative indicator of the content of substances dissolved in water. Among the most common are inorganic salts (mainly bicarbonates, chlorides and sulfates of calcium, magnesium, potassium and sodium) and a small amount of organic substances soluble in water. The level of salinity is due to the geological features of the region because of the different solubility of minerals. In addition to natural factors, industrial wastewater and urban storm runoff have a great influence on the general mineralization of water.

Particular attention during the study was given to the determination of heavy metals in the water of surface water bodies. Exceeding the maximum permissible concentrations (MPC) is dangerous from the point of view of exposure to all environmental components due to its high toxicity and ability to accumulate in living organisms and bottom sediments [18, p. 59].

The study of water from the rivers of the Sverdlovsk region showed excess MPC for a number of heavy metals.

The results of the study are shown in table 2 .

As can be seen from the table, in all the rivers of the Middle Urals studied by us, an excess of the concentration of heavy metals was found, while in the river Pozarishka the excess is noted for all the elements that interest us. The highest MPC excess in the water of this river falls on such heavy metals 
as cobalt, copper, nickel, lead and zinc, of which all but lead belong to hazard class III, lead to class II, all elements are toxic. Water pollution with cadmium was noted only in the Pozarishka River, the excess was 1.3 MPC. This indicator belongs to hazard class II, the element is toxic. Cadmium has the ability to accumulate in living organisms and have an acute toxic effect on them, including humans [18, p. 58].

Lead concentrations in natural waters exceeding background values are due to anthropogenic stress. A significant contribution to environmental pollution by lead compounds along with the activities of the chemical and metallurgical industries is made by the burning of coal and the use of lead compounds in motor fuels [11, p. 440].

Cadmium and lead are toxic metals that are harmful and not biodegradable [7, p. 390].

The figure shows the excess of the MPC of heavy metals in the water of the studied rivers relative to the standards for the content of these elements established for fishery reservoirs.

It can be seen from the figure that the greatest excess of the limit concentrations for cobalt was found in the Pozarishka river and amounts to almost $32 \mathrm{MPC}$, also an excess of cadmium concentration was found in this river, in other rivers this indicator was within the normal range.

In all rivers, the excess concentration of manganese was almost at the same level. So, in the Iset, Baltym and Manchazh rivers, the excess was 1.3 MPC, in the Brusyanka River - 1.6 MPC, the largest excess - 1.9 MPC in the Pozarishka River.

The copper concentration is significantly exceeded in all rivers, its indicators vary from $12 \mathrm{MPC}$ in the Pozarishka River, to $3 \mathrm{MPC}$ in the Manchazh River, an average of $8 \mathrm{MPC}$ refers to the Baltym River.
Exceeding the normal values of the content of nickel heavy metal salts in the water of rivers amounted to 10.3 MPC for the Pozarishka River, almost 9 MPC for the Brusyanka and Baltym rivers, 7 MPC for the Manchazh River, and 3.5 MPC for the Iset River.

It is worth noting that in all the studied water bodies an excess of the maximum lead concentration was found, the indicators range from 0.062 in the Iset River to a maximum of 0.106 in the Pozarishka and Manchazh rivers, the excess is 10.3 and 17.6 MPC, respectively.

Thus, the Manchazh river is the least polluted by heavy metals (according to the results of our research), this is explained by the fact that it flows in a zone with a low technogenic load, there are no large industrial enterprises in the Artinskiy district, the main sources of water pollution are transport and agriculture.

\section{Discussion and Conclusion}

From the results of the study, it becomes clear that the most polluted in terms of the studied indicators is the Pozarishka River, flowing through the territory of the Kamenskiy district. Here is observed an excess for all studied heavy metals belonging to hazard class II and III. This is due to the fact that this territory is located in the zone of the East Ural radioactive trail. In addition, there are concentrated a large number of industrial enterprises in this area.

The Brusyanka river of the Beloyarskiy district and the Baltym river of the Verkhnyaya Pyshma urban district turned out to be approximately the same in terms of pollution. A number of indicators in these rivers had the same MPC excess. However, a greater excess of zinc, copper and cobalt concentrations was noted in the Brusyanka river. Thus, this river can be put in second place in terms of the number of toxic substances in the water, and the Baltym River - in third place.

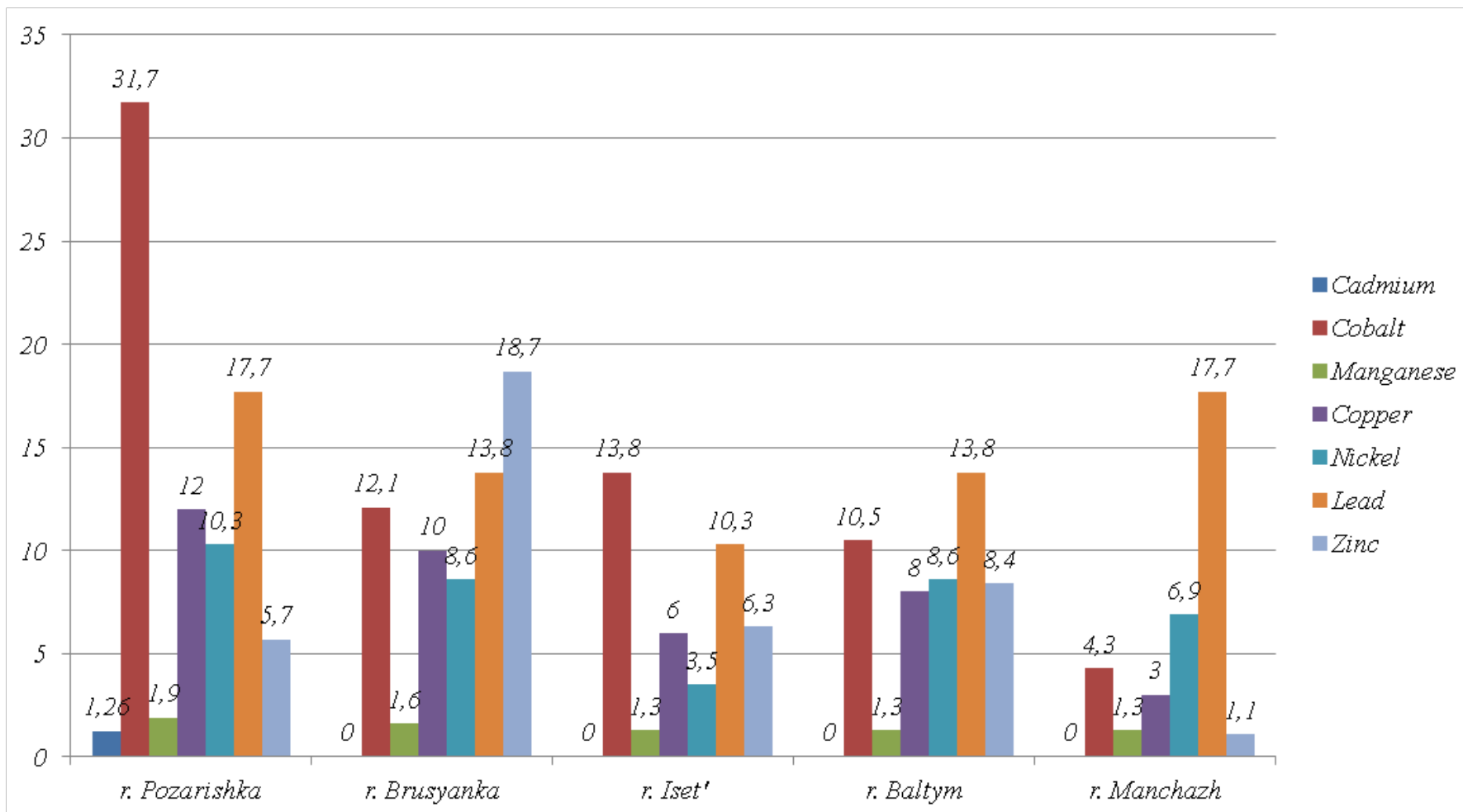

Fig. Multiplicity exceeding the MPC of heavy metals in flowing water bodies of the Middle Urals 
The fourth place in terms of water pollution by heavy metals as a result of our research was the Iset' River. The sampling point for water from this river is located in the Sysert' district (Bolshoy Istok). There are no large industrial enterprises on the territory, but the city of Ekaterinburg was founded on the banks of this river and today, with the active development of industry, the river performs the most important function - it works as a sewage discharge system.

Based on the ecological reports of the region, the Iset' River is recognized as the most polluted river in the Sverdlovsk Region. The main toxic load falls on the river in areas close to the two largest industrial cities Ekaterinburg and KamenskUralskiy. Thus, this river is polluted along its entire length, which explains its pollution in the Sysert' district, where there are no significant industrial discharges.
The Manchazh River, which is located in a zone with a low technogenic load, turned out to be the least polluted; there are no large industrial enterprises in the area where this river flows.

It can be assumed that when using water from these rivers to irrigate the fields on which crops are grown for further feeding of cattle, as well as to drink it during grazing, heavy metals in the water will enter the body of animals and then get into them agricultural products.

It is worth noting that the largest excesses in all rivers are noted for lead and cobalt, the main sources of which are the exhaust gases of automobiles.

Based on the results of the study, the following conclusion can be made: in areas with unfavorable environmental conditions that have sources of technogenic pollution, it is necessary to conduct a comprehensive study of the level of environmental pollution and take measures to minimize them.

\section{References}

1. Pakhal'chak G. Yu. Gosudarstvo, trebuya ot predpriyatiy vypolneniya prirodookhrannykh meropriyatiy, svoi sobstvennye obyazannosti ne toropitsya vypolnyat' [The state, requiring enterprises to carry out environmental protection measures, is in no hurry to fulfill their own responsibilities] // Discussion. 2016. No. 7 (70). Pp. 6-12. (In Russian.)

2. Gosudarstvennyy doklad o sostoyanii ob okhrane okruzhayushchey sredy Sverdlovskoy oblasti v 2016 godu [State report on the state and environmental protection of the Sverdlovsk region in 2016]. Ekaterinburg, 2017. 306 p. (In Russian.)

3. Gutova M. O. Otsenka ekologicheskogo blagopoluchiya rek Srednego Urala v zonakh s povyshennoy tekhnogennoy nagruzkoy [Assessment of the ecological well-being of the rivers of the Middle Urals in areas with increased technogenic load] // Ekologo-biologicheskie problemy ispol'zovaniya prirodnykh resursov v sel'skom khozyaystve: sbornik materialov IV Mezhdunarodnoy nauchno-prakticheskoy konferentsii molodykh uchenykh i spetsialistov. Ekaterinburg, 2018. Pp. $163-167$. (In Russian.)

4. Gutova M. O., Flefel' Kh. E., Donnik I. M., Gribovskiy Yu. G. Otsenka kontsentratsii tyazhelykh metallov Fe, Zn, Cd i Pb $\mathrm{v}$ prirodnykh vodoistochnikakh [Estimation of the concentration of heavy metals $\mathrm{Fe}, \mathrm{Zn}, \mathrm{Cd}$ and $\mathrm{Pb}$ in natural water sources] // Agrarian Bulletin of the Urals. 2019. No. 6 (185). Pp. 44-47. (In Russian.)

5. Osman A., Kloas W., Fisheries I. Water Quality and Heavy Metal Monitoring in Water, Sediments and Tissues of the African Catfish Clarias gariepinus (Burchell, 1822 ) from the River Nile, Egypt // Journal of Environmental Protection. 2010. No. 1 (04). Pp. 389-400.

6. Srivastava S., Srivastava A. K., Suprasanna P., Souza S. F. D. Comparative biochemical and transcriptional profiling of two contrasting varieties of Brassica juncea L. In response to arsenic exposure reveals mechanisms of stress perception and tolerance // Journal of experimental botany. 2009. Vol. 60. No. 12. Pp. 3419-3431.

7. Maurya R. R. Determination of Physico-Chemical Parameters and Water Quality Index (Wqi) of Chandlodia Lake, Ahmedabad, Gujarat, India // Journal of Environmental and Analytical Toxicology. 2015. Vol. 05. No. 04. Pp. 1-6.

8. Gutova M. O., Flefel' Kh. Ekologicheskiy monitoring snezhnogo pokrova Sverdlovskoy oblasti [Environmental monitoring of the snow cover of the Sverdlovsk region] // Razrabotka otechestvennykh veterinarnykh preparatov i sposobov profilaktiki i lecheniya zabolevaniy sel'skokhozyaystvennykh zhivotnykh i ptits: sbornik trudov konferentsii. Ekaterinburg, 2018. Pp. 7278. (In Russian.)

9. Mahajan V. S., Pokale S.S. Studies on Physico-chemical analysis of Mohabala Lake near Bhadrawati, District Chandrapur (MS), India // International Journal of Life Sciences. 2017. Vol. 5. No. 3. Pp. 438-446.

10. Baytimirova E. A., Mikheeva E. V., Bespamyatnykh E. N., Donnik I. M., Krivonogova A. S. Otsenka zagryazneniya rek reatsionnykh zon megapolisa tyazhelymi metallami (na primere Ekaterinburga) [Assessment of pollution of recreational areas of a metropolis by heavy metals (on the example of Ekaterinburg)] // Agrarian Bulletin of the Urals. 2016. No. 4 (146). Pp. 71-77. (In Russian.)

11. Gribovskiy Yu. G., Nokhrin D. Yu., Davydova N. A., Kolesnik E. A. Soderzhanie tyazhelykh metallov v vode I donnykh otlozheniyakh presnovodnykh vodoemov Chelyabinskoy oblasti [The content of heavy metals in water and bottom sediments of freshwater reservoirs of the Chelyabinsk region] // Agrarian Bulletin of the Urals. 2018. No. 9 (176). Pp. 26-32. (In Russian.)

12. Seleznev A. A., Yarmoshenoko I. V., Savast'yanova A. S., Makarov A. B. Sovremennye antropogennye otlozheniya I ikh ispol'zovanie dlya otsenki ekologicheskogo sostoyaniya urbanizirovannykh territoriy [Modern anthropogenic deposits and their use for assessing the ecological state of urbanized territories] // Izvestiâ Ural'skogo gosudarstvennogo gornogo universiteta. 2017. Iss. 1 (45). Pp. 44-49. (In Russian.)

13. Davydova O. A., Klimov E. S., Vaganova E. S., Vaganov A. S. Vliyanie fiziko-khimicheskikh faktorov na soderzhanie tyazhelykh metallov $\mathrm{v}$ vodnykh ekosistemakh [The influence of physico-chemical factors on the content of heavy metals in aquatic ecosystems]. Ulyanovsk: U1STU, 2014. 167 p. (In Russian.) 
14. Khound Nayan J., Phukon Parag, Bhattacharyya Krishna G. Toxic Trace Metals in the Surface Water Sources of Jia Bharali River Basin, North Brahmaputra Plain, India - A Hydrochemical Elucidation // Water Resources. 2019. Vol. 46. No. 1. Pp. 117-127.

15. Mirzoev E. B., Kobyalko V. O., Polyakova I. V., Gubina O. A. Metabolizm svintsa I mekhanizmy ego tsitotoksicheskogo deystviya $\mathrm{v}$ organizme mlekopitayushchikh [Lead metabolism and mechanisms of its cytotoxic action in mammals] // Sel'skokhozyaistvennaya biologiya. 2018. Vol. 53. No. 6. Pp. 1131-1141. (In Russian.)

16. Donnik I. M., Shkuratova I. A., Isaeva A. G., Vereshchak N. A., Krivonogova A. S., Beykin Ya. B., Portnov V. S., Barashkin M. I., Loretts O. G. Fiziologicheskie osobennosti zhivotnykh v rayonakh tekhnogennogo zagryazneniya [Physiological characteristics of animals in areas of technogenic pollution] // Agrarian Bulletin of the Urals. 2012. No. 1 (93). 2012. Pp. 26-28. (In Russian.)

17. Gudieva I. R. Fiziologicheskie svoystva kobal'ta i ego vliyanie na organism cheloveka [Physiological properties of cobalt and its effect on the human body] // Molodoy uchenyy. 2019. No. 5 (243). Pp. 42-46. (In Russian.)

18. Ivanyutin N. M., Podovalova S. V. Otsenka sovremennogo ekologicheskogo sostoyaniya reki Biyuk-Karasu [Assessment of the current ecological state of the Biyuk-Karasu River] // Water and Ecology: Problems and Solutions. 2019. No. 1 (77). Pp. 58-63. (In Russian.)

19. Tkachenko A. V., Il'ichenko G. V., Shipkova L. N. Issledovanie pollyutantov rechnoy vody, vliyayushchikh na zdorov'e cheloveka [Study of river water pollutants affecting human health] // The Journal of scientific articles "Health and Education Millenium". 2018. Vol. 20. No. 4. Pp. 149-151. (In Russian.)

\section{Authors' information:}

Mariya O. Gutova ${ }^{1}$, postgraduate, ORCID 0000-0002-0067-1504, AuthorID 1069654; +7 965 543-98-55, maaniassha@mail.ru

Khassan E. Flefel ${ }^{1}$, postgraduate, ORCID 0000-0003-4406-9221, AuthorID 1074034; +7 922 292-72-31, hflefel@hotmail.com Marina S. Andryushechkina ${ }^{1}$, postgraduate, ORCID 0000-0003-1463-4605, AuthorID 1073935; +7 904 380-43-55,

Marya-92@yandex.ru

${ }^{1}$ Ural State Agrarian University, Ekaterinburg, Russia 